\title{
ANALISIS PERILAKU PEDAGANG DI PASAR IKAN FLAMBOYAN DI PONTIANAK
}

\author{
Andry Lindi Lim, S.E., M.M. \\ email: Vaynard northgard@yahoo.com \\ STIE Widya Dharma Pontianak
}

\begin{abstract}
Abstrak
Masalah dalam penelitian ini adalah perilaku pedagang, dan penulis membatasi pada: Analisis budaya, analisis sosial, analisis pribadi, dan analisis psikologis. Metode deskriptif, dan teknik pengumpulan data dengan melakukan wawancara dan mendistribusikan kuesioner. Populasi adalah pedagang ikan di Pasar Ikan Flamboyan di Pontianak. Teknik pengambilan sampel dari populasi menggunakan simple random sampling dengan 50 responden. Dapat disimpulkan bahwa secara keseluruhan dan dirata-ratakan responden setuju dengan analisis perilaku pedagang yang mencakup faktor budaya, faktor sosial, faktor pribadi, faktor psikologis perilaku pedagang. Variabel budaya memiliki rata-rata keseluruhan 4,01, variabel sosial memiliki rata-rata keseluruhan 3,78, variabel pribadi memiliki rata-rata keseluruhan 3,65, dan variabel psikologis memiliki rata-rata keseluruhan 3,69
\end{abstract}

Kata kunci: Analisis Perilaku Pedagang

\begin{abstract}
The problems in this study are merchant behavior, and the author limits on: Cultural analysis, social analysis, personal analysis, and psychological analysis. Descriptive methods, and data collection techniques by conducting interviews and distributing questionnaires. The population is fish traders at Flamboyan Fish Market in Pontianak. Sampling technique from the population using simple random sampling with 50 respondents. It can be concluded that overall and averaged respondents agreed with the analysis of trader behavior which includes cultural factors, social factors, personal factors, psychological factors of trader behavior. The cultural variable has an overall average of 4.01, the social variable has an overall average of 3.78 , the private variable has an overall average of 3.65 , and the psychological variable has an overall average of 3.69 .
\end{abstract}

Key words: The Analysis of Merchant Behavior

\section{A. Pendahuluan}

Pasar ikan adalah pasar yang digunakan untuk memasarkan ikan dan produk ikan. Selain ikan, organisme akuatik dan boga bahari lainnya juga dijual, seperti cumi dan udang. Pasar ikan dapat ditujukan untuk menjual ikan secara grosir kepada pedagang ikan lain atau secara eceran kepada konsumen. Pasar ikan juga menjual aneka jajanan yang terbuat dari hasil laut, dan restoran serta warung makan yang khusus menyajikan masakan ikan juga berdiri di dekat pasar ikan. Ukuran pasar ikan bervariasi dari gerai kecil, hingga pasar besar. Menurut Soekartawi 
(1995: 27) pendapatan sangat dipengaruhi oleh banyaknya ikan yang dijual oleh pedagang sendiri sehingga semakin banyak jumlah ikan maka semakin tinggi pendapatan yang diperoleh.

Pemerintah Kota Pontianak berencana melakukan pembangunan pasar ikan di Pasar Flamboyan. Rencana pembangunan pasar ikan di pasar tradisional terbesar di Kota Pontianak ini diharapkan mendapat dukungan dari para pedagang.

"Menerima pembangunan tersebut bila jadi dibangun," kata Wali Kota Pontianak Sutarmidji di ruang kerjanya. Pontianak Post, Selasa (4/7/2017). Menurutnya, pembangunan ini perlu dilakukan karena melihat kondisi pasar ikan Flamboyan sekarang yang kurang nyaman. Sementara Pemkot Pontianak harus memberikan kenyamanan dan pelayanan publik yang baik untuk masyarakat dalam berbelanja. "Jadi tidak lagi memandang dari sisi kepentingan pedagang, tetapi juga kepentingan pembeli," lugasnya. Sebelumnya kata dia, ingin membangun pasar ikan itu bersamaan dengan pembangunan Pasar Flamboyan. Namun kala itu ada keinginan dari para pedagang pasar ikan yang ingin membangun sendiri pasar itu. "Keinginan mereka itu jelas dan ada berita acara penolakannya dalam bentuk notulen rapatnya," ungkapnya.

Dijelaskan Sutarmidji, ada dua konsep pembangunan pasar ikan Flamboyan. Opsi pertama, pihaknya akan meminta bantuan anggaran dari pemerintah pusat. Seandainya pembangunan itu anggarannya dari pusat, maka Pasar Flamboyan itu dibongkar habis dan dibangun baru. Opsi kedua, dengan pola rehabilitasi berat yang bisa menggunakan APBD Kota Pontianak. Rehab berat ini mencakup peninggian lantai dan mejanya diganti seluruhnya. Sedangkan yang lainnya tetap, sebab bangunan bagian atas dinilainya masih layak.

Dirinya juga ingin penanganan pasar itu melibatkan para pelaku usaha, baik perencanaan maupun pengaturannya. "Masalah letak meja dan lain sebagainya silakan pedagang yang atur, kenyamanan dan sirkulasi di sana. Masalah kepemilikan itu juga tidak kita ganggu. Kecuali ada penambahan ruang tempat, itu dibicarakan secara baik," jelasnya. Demi kenyamanan pedagang dan pembeli, ia meminta tidak ada lagi penolakan pembangunan pasar ikan. Sebab hal ini penting dan perlu untuk dibangun sebagai bagian dari penataan fasilitas kota. Bahkan, dirinya sempat berpikir, bila memang masih ada penolakan, pihaknya akan mencari tempat untuk membangun fresh mart. Sutarmidji menyebut, ada pihak swasta yang siap membangun pasar untuk menjual ikan dan lain sebagainya. "Tetapi saya masih berpikir lebih baik kita yang menata pasar ikan supaya lebih nyaman dan pembeli lebih leluasa," ujarnya. 
Penangkapan ikan komersial adalah aktivitas penangkapan ikan dan boga bahari lainnya untuk tujuan keuntungan komersial. Sebagian besar dalam bentuk perikanan tangkap, sebagian lainnya berupa perikanan budi daya.Penangkapan ikan komersial menyediakan sejumlah besar bahan pangan ke berbagai negara di seluruh dunia, dan seringkali ikan dikejar hingga jauh ke tengah lautan, terutama oleh pelaku industri perikanan. Industri harus beradaptasi sepanjang tahun keberadaan usahanya untuk menuju keuntungan yang besar.Sebuah studi yang didapatkan dari penangkapan komersial kecil milik keluarga menunjukkan bahwa mereka melakukan usaha penangkapan ikan bukan untuk mendapatkan keuntungan, melainkan untuk menghidupi. Penangkap ikan komersial memanen berbagai jenis hewan, antara lain tuna, kakap, dan tenggiri. Selain ikan, mereka juga menangkap tangkapan lain, antara lain: udang, lobster, kerang, cumicumi, dan kepiting.

Kepala Disperindagkop dan UKM Kota Pontianak, Haryadi melihat, kurangnya distribusi ikan dari nelayan Kalbar bisa berpengaruh dengan jumlah pasokan ikan. Jika pasokan kurang akan mempengaruhi harga jual tiap jenis ikan. "Permintaan tetap, namun pasokan berkurang, menimbulkan kenaikan harga, itu jelas," terangnya. Untuk meminimalisir kenaikan, otomatis distribusi ikan didatangkan dari beberapa wilayah lain. Hanya saja, apakah harga jual dari luar Kalimantan sama dengan harga yang dijual nelayan Kalbar. Hingga saat ini, pantauan Disperindagkop harga jual ikan masih relatif normal, itu karena jumlah ikan saat ini masih bisa mengimbangi kebutuhan masyarakat. Pontianak Post, Senin (11/4/2017).

Ketua Gabungan Pedagang Ikan (Gapikan) Pontianak, Yuhendra mengakui, sebagian pasokan ikan yang masuk ke Pontianak berasal dari Kalimantan Tengah, Kalimantan Selatan, dan beberapa daerah lain. Menurutnya, distribusi panganan laut dari beberapa tempat itu, bisa menekan harga jual ikan yang beberapa waktu lalu melonjak.Tak melautnya nelayan Kalbar beberapa bulan terakhir akibat terbentur persoalan administrasi dari Menteri Kelautan dan Perikanan turut memengaruhi jumlah pasokan ikan yang masuk ke pasar tradisional ini."Harga jual ikan kalau seminggu lalu naik. Untuk jenis tenggiri bisa sampai Rp45.000,00 per kilo. Beberapa hari terakhir harga ikan mulai turun, karena bulan ini musim ikan," ucapnya kepada Pontianak Post, Senin (11/4/2017).

Saat ini, kebanyakan ikan didatangkan agen dari beberapa tempat, seperti Kalteng, Kalsel dan beberapa daerah di Pulau Kalimantan."Di sini (Pasar Flamboyan) sebagian pasokan dari Kalteng dan Kalsel dengan agen bisa mencapai lima orang.Untuk kualitas ikan saya rasa tak jauh 
dengan nelayan di sini," ungkapnya. Setidaknya, pasokan ikan yang datang dari luar daerah bisa menekan harga jual ikan agar tidak melambung. Menurut informasi, banyak nelayan Kalbar tidak berani melaut karena takut dirazia oleh pihak terkait akibat administrasi yang tak lengkap dan soal pukat yang digunakan.Persoalan ini tentu berpengaruh ke pedagang.Apabila pasokan dari nelayan Kalbar kurang dan sedikitnya jumlah ikan yang dipasok, membuat harga jual tinggi. “Untuk Pontianak, dalam satu harinya bisa menjual hingga 20 ton ikan, bahkan lebih," ujarnya.

Memang dalam hal ini pemerintah ada benarnya. Pemerintah ingin melindungi kekayaan bawah laut. Menurut informasi, sebagian nelayan menangkap ikan menggunakan pukat tertentu, akibatnya tidak sedikit terumbu karang yang masuk ke dalam pukat itu. Agar nelayan dapat melaut kembali tanpa melanggar aturan dari pemerintah, persoalan ini mesti dicari solusinya.Apabila tidak ditindaklanjuti, bisa saja pasokan ikan dari nelayan Kalbar berkurang karena takut melaut untuk menghindari razia oleh petugas.'Bulan lalu pasokan ikan memang minim, untung ada distribusi ikan dari luar, sehingga kita bisa memenuhi kebutuhan masyarakat," tukasnya.

Berdasarkan latar belakang permasalahan tersebut, peneliti tertarik melakukan penelitian untuk mengetahui faktor budaya, faktor sosial, faktor pribadi, faktor psikologis perilaku pedagang. Permasalahan dalam penelitian ini adalah perilaku pedagang di Pasar Ikan Flamboyan di Pontianak, dan penulis membatasi pada:

1. Analisis budaya,

2. Analisis sosial,

3. Analisis pribadi, dan

4. Analisis psikologis.

\section{B. Landasan Teori}

Kotler (2001: 21) berpendapat bahwa proses sosial di mana dengan proses itu, individu dan kelompok mendapatkan apa yang mereka butuhkan dan inginkan dengan menciptakan, menawarkan, dan secara bebas mempertukarkan produk dan jasa yang bernilai dengan pihak lain. Perilaku tenaga penjual oleh Babakus, et al dalam Adriani (2006: 36) didefinisikan sebagai evaluasi dari berbagai aktivitas dan strategi yang digunakan oleh tenaga penjual ketika melakukan tanggung jawab pekerjaannya. Permasalahan terkait pengelolaan pasar tradisional antara lain, citra negatif pasar tradisional pada umumnya terjadi akibat kurang 
disiplinnya pedagang, pengelola pasar yang tidak profesional, tidak tegas dalam menerapkan kebijakan atau aturan terkait pengelolaan operasional pasar, buruknya manajemen pasar dan kurang pahamnya pedagang dalam menerapkan konsep pemasaran yang baik.

Pertimbangan-pertimbangan yang cermat dalam menentukan lokasi menurut Tjiptono dalam Ghazali (2010: 73) meliputi faktor-faktor:

a. Akses, misalnya lokasi yang mudah dijangkau sarana transportasi umum.

b. Visibilitas, misalnya lokasi dapat dilihat dengan jelas dari tepi jalan.

c. Tempat parkir yang luas dan aman.

d. Ekspansi, yaitu tersedia tempat yang cukup luas untuk perluasan usaha kelak.

e. Lingkungan, yaitu daerah sekitar yang mendukung jasa yang ditawarkan.

Menurut Winardi dalam Deka I Djakarta (2012: 28), harga dapat diukur melalui:

a. Tingkat harga.

b. Harga produk pesaing.

c. Diskon (potongan pembelian).

d. Periode pembayaran.

e. Variasi sistem pembayaran.

Promosi menurut Dharmmesta dalam Anggaraeni (2007: 22) adalah arus informasi atau persuasi satu arah yang dibuat untuk menggerakkan seseorang atau organisasi kepada tindakan yang menciptakan pertukaran dalam pemasaran.Yuliarsih dalam Saefulamri (2012: 27) berpendapat bahwa Kebersihan mempunyai pengaruh positif terhadap perpindahan konsumen dalam menentukan tempat pembelian atau tempat berbelanja.Kotler dan Armstrong dalam Saefulamri (2012: 24) berpendapat bahwa kualitas dan peningkatan produk merupakan bagian yang penting dalam strategi pemasaran.

Menurut Kotler dan Armstrong (2001: 91) terdapat beberapa faktor yang mempengaruhi perilaku konsumen, yaitu faktor budaya, sosial, pribadi dan psikologis:

1. Faktor budaya merupakan bentuk paling dasar dari keinginan dan perilaku seseorang. Budaya meliputi nilai-nilai dasar, persepsi, pilihan, dan perilaku yang dipelajari seseorang dari keluarga dan institusi penting lainnya. Sub kebudayaan adalah budaya di dalam suatu budaya 


\section{Vol. 4 No. 2 Firm Journal of Management Studies}

yang memiliki nilai dan gaya hidup yang berbeda dan dapat berdasarkan apapun mulai dari unsur sampai etnis.

2. Faktor sosial juga mempengaruhi perilaku pembelian. Kelompok acuan seseorang seperti keluarga, rekan, organisasi sosial, asosiasi profesi dengan kuat mempengaruhi pemilihan produk dan merek.

3. Faktor pribadi mempengaruhi seorang pembeli dalam membuat keputusan. Karakteristik pribadi itu meliputi umur, tahap siklus hidup, pekerjaan, lingkungan ekonomi, gaya hidup dan kepribadian.

4. Faktor psikologis yang terdiri dari motivasi, persepsi, proses belajar dan keyakinan juga mempengaruhi perilaku pembelian konsumen.

Dharmmesta dan Handoko (2017: 43) berpendapat bahwa faktor-faktor yang mempengaruhi perilaku konsumen dikelompokkan menjadi tiga, yaitu:

1. Faktor-faktor ekstern yang mempengaruhi perilaku konsumen, terdiri atas faktor kebudayaan, kelas sosial, kelompok-kelompok sosial dan referensi, serta keluarga.

2. Faktor-faktor intern atau individu yang menentukan perilaku, terdiri atas faktor motivasi, persepsi, kepribadian dan konsep diri, belajar dan sikap dari individu.

3. Proses pengambilan keputusan konsumen.

Proses ini terdiri dari lima tahap, yaitu:

a. Menganalisis keinginan dan kebutuhan,

b. Pencarian informasi,

c. Seleksi terhadap alternatif pembelian,

d. Keputusan untuk membeli, dan

e. Perilaku sesudah pembelian.

Purnama (2002: 78) berpendapat bahwa lingkungan adalah faktor yang ikut mempengaruhi konsumen karena sifatnya yang kompleks. Perilaku proses keputusan konsumen, biasanya dipengaruhi oleh lima faktor yaitu:

1. Budaya

Adalah seperangkat nilai, gagasan, artefak, dan simbol-simbol lain yang bermakna yang membantu individu untuk berkomunikasi, melakukan penafsiran dan evaluasi sebagai anggota 


\section{Vol. 4 No. 2 Firm Journal of Management Studies}

masyarakat. Budaya merupakan sesuatu yang khas, budaya satu orang dengan lainnya berbeda.

2. Kelas sosial

Kelas sosial merupakan pembagian dalam masyarakat yang terdiri dari individu-individu yang berbagi nilai, minat, dan perilaku yang sama. Mereka dibedakan oleh perbedaan status, sosioekonomi yang berjajar dari yang rendah sampai yang tinggi.Kelas sosial dapat menghasilkan bentuk-bentuk perilaku konsumen yang berbeda-beda.

\section{Pengaruh pribadi}

Sebagai konsumen, perilaku individu seringkali dipengaruhi oleh mereka yang erat hubungannya dengan individu yang bersangkutan. Tiap individu mungkin merespon terhadap tekanan yang dirasakan dan menyesuaikan diri dengan norma dan harapan yang diberikan oleh orang lain.

4. Keluarga

Keluarga adalah sebuah kelompok yang terdiri dari dua orang atau lebih yang terikat oleh perkawinan, darah (keturunan) dan adopsi yang tinggal bersama dalam satu rumah.Keluarga menjadi fokus penelitian karena keluarga merupakan fungsi pengambilan keputusan utama, dengan pola peranan dan fungsi yang kompleks dan bervariasi.

\section{Situasi}

Situasi sangat mempengaruhi perilaku pembelian, karena perilaku akan berubah ketika situasi berubah. Kadangkala perubahan tersebut tidak menentu dan tidak dapat diramalkan.

Permasalahan dalam penelitian ini adalah perilaku pedagang di Pasar Ikan Flamboyan di Pontianak, dan penulis membatasi pada:
a) Analisis budaya,
b) Analisis sosial,
c) Analisis pribadi, dan
d) Analisis psikologis.

\section{Metode Penelitian}

Metode deskriptif, dan teknik pengumpulan data dengan melakukan wawancara dan menyebarkan kuesioner. Populasi adalah para pedagang ikan di Pasar Ikan Flamboyan di 
Pontianak. Teknik pengambilan sampel dari populasi menggunakan Simple Random Sampling dengan responden 50 orang.

\section{Hasil Analisis dan Pembahasan}

Profil responden mencakup para pedagang ikan di Pasar Ikan Flamboyan di Pontianak dengan lama berjualan ikan minimal sama atau lebih dari satu tahun, dan mencakup analisis-analisis sebagai berikut:

\section{Analisis Variabel dan Indikator}

Berikut diuraikan analisis tanggapan responden terhadap masing-masing variabel:

TABEL 1

VARIABEL DAN INDIKATOR

\begin{tabular}{|l|l|}
\hline \multicolumn{1}{|c|}{ Variabel } & \\
\hline Budaya & $\begin{array}{l}\text { a. Kebudayaan } \\
\text { b. Sub Kebudayaan } \\
\text { c. Kelas Sosial }\end{array}$ \\
\hline Sosial & $\begin{array}{l}\text { a. Kelompok Acuan } \\
\text { b. Keluarga } \\
\text { c. Peran dan Status }\end{array}$ \\
\hline Pribadi & $\begin{array}{l}\text { a. Umur dan Tahap Siklus Hidup } \\
\text { b. Pekerjaan }\end{array}$ \\
& $\begin{array}{l}\text { c. Situasi Ekonomi } \\
\text { d. Gaya Hidup } \\
\text { e. Kepribadian dan Konsep Diri }\end{array}$ \\
\hline Psikologis & $\begin{array}{l}\text { a. Motivasi } \\
\text { b. Persepsi } \\
\text { c. Pengetahuan } \\
\text { d. Keyakinan } \\
\text { e. Sikap }\end{array}$ \\
\hline
\end{tabular}

Sumber: Data olahan, 2018 


\section{Analisis Rekapitulasi Hasil Tanggapan Dominan Responden}

TABEL 2

REKAPITULASI HASIL TANGGAPAN DOMINAN RESPONDEN

\begin{tabular}{|c|c|c|c|}
\hline No. & Pernyataan & $\begin{array}{c}\text { Nilai } \\
\text { Rata-rata }\end{array}$ & Kriteria \\
\hline & Budaya & & \\
\hline 1 & Kebudayaan & 4,14 & Setuju \\
\hline 2 & Sub Kebudayaan & 3,92 & Setuju \\
\hline \multirow[t]{3}{*}{3} & Kelas Sosial & 3,96 & Setuju \\
\hline & Rata-rata Keseluruhan & 4,01 & \\
\hline & Sosial & & \\
\hline 1 & Kelompok Acuan & 3,94 & Setuju \\
\hline 2 & Keluarga & 3,68 & Setuju \\
\hline \multirow[t]{3}{*}{3} & Peran dan Status & 3,72 & Setuju \\
\hline & Rata-rata Keseluruhan & 3,78 & \\
\hline & Pribadi & & \\
\hline 1 & Umur dan Tahap Siklus Hidup & 3,72 & Setuju \\
\hline 2 & Pekerjaan & 3,18 & Setuju \\
\hline 3 & Situasi Ekonomi & 3,86 & Setuju \\
\hline 4 & Gaya Hidup & 3,72 & Setuju \\
\hline \multirow[t]{3}{*}{5} & Kepribadian dan Konsep Diri & 3,78 & Setuju \\
\hline & Rata-rata Keseluruhan & 3,65 & \\
\hline & Psikologis & & \\
\hline 1 & Motivasi & 3,82 & Setuju \\
\hline 2 & Persepsi & 3,58 & Setuju \\
\hline 3 & Pengetahuan & 3,38 & Setuju \\
\hline 4 & Keyakinan & 3,82 & Setuju \\
\hline \multirow[t]{2}{*}{5} & Sikap & 3,84 & Setuju \\
\hline & Rata-rata Keseluruhan & 3,69 & \\
\hline
\end{tabular}

Sumber: Data olahan, 2018

Berdasarkan Tabel 2 dapat diketahui hasil analisis perilaku pedagang bahwa variabel budaya mempunyai rata-rata keseluruhan sebesar 4,01, variabel sosial mempunyai rata-rata keseluruhan sebesar 3,78, variabel pribadi mempunyai rata-rata keseluruhan sebesar 3,65, dan variabel psikologis mempunyai rata-rata keseluruhan sebesar 3,69. 


\section{Analisis Urutan Tingkat Nilai Rata-rata Keseluruhan Tertinggi Sampai Terendah}

TABEL 3

URUTAN TINGKAT NILAI RATA-RATA KESELURUHAN

TERTINGGI SAMPAI TERENDAH

\begin{tabular}{|c|l|c|}
\hline No. & \multicolumn{1}{|c|}{ Variabel } & $\begin{array}{c}\text { Nilai Rata-rata } \\
\text { Keseluruhan }\end{array}$ \\
\hline 1 & Budaya & 4,01 \\
\hline 2 & Sosial & 3,78 \\
\hline 3 & Pribadi & 3,65 \\
\hline 4 & Psikologis & 3,69 \\
\hline
\end{tabular}

Sumber: Data olahan, 2018

Berdasarkan hasil analisis bauran pemasaran ritel pada perusahaan bahwa nilai rata-rata tertinggi dari keempat variabel tersebut adalah variabel budaya yaitu sebesar 4,01, sedangkan nilai rata-rata terendah adalah variabel pribadi yaitu sebesar 3,65.

\section{E. Kesimpulan dan Saran}

\section{Kesimpulan}

Berdasarkan hasil analisis dan pembahasan yang telah dilakukan oleh penulis, maka dapat disimpulkan bahwa secara keseluruhan dan dirata-ratakan responden setuju dengan analisis perilaku pedagang yang mencakup faktor budaya, faktor sosial, faktor pribadi, faktor psikologis perilaku pedagang.

\section{Saran-saran}

Berdasarkan kesimpulan tersebut, maka saran yang dapat penulis berikan kepada Pemerintah Kota Pontianak, pada khususnya dapat lebih memperhatikan program-program berbasis psikologis.

\section{DAFTAR PUSTAKA}

Adriani, Ririn. (2006). Analisis Faktor-faktor yang Mempengaruhi Perilaku Tenaga Penjual Untuk Meningkatkan Kinerja Tenaga Penjual Semarang: Universitas Dipenogoro.

Anggraeni, Retno. (2007). Analisis Persepsi Konsumen Terhadap Bauran Pemasaran Jasa pada PT (Persero) DAMRI di Pontianak. Pontianak: Universitas Tanjungpura. 
Dharmmesta, Basu Swastha dan T. Hani Handoko. (2017). Manajemen Pemasaran-Analisis Perilaku Konsumen. Yogyakarta: BPFE.

Ghazali, Rizwar. (2010). Analisis Pengaruh Bauran Pemasaran Produk Plastik Terhadap Volume Penjualan PT Mitraya Plasindo Sejati. Semarang: Universitas Diponegoro.

Kotler, Philip. (2001). Manajemen Pemasaran. Jakarta: Erlangga.

Kotler, Philip dan Gary Armstrong. (2001). Prinsip-prinsip Pemasaran. Jakarta: Erlangga.

Purnama, C. M. Lingga. (2002). Strategic Marketing Plan-Panduan Lengkap dan Praktis Menyusun Rencana Pemasaran yang Strategis dan Efektif. Jakarta: Gramedia Pustaka Utama.

Saefulamri. (2012). Analisis Pengaruh Kualitas Produk, Kebersihan dan Kenyamanan di Pasar Tradisional Terhadap Perpindahan Berbelanja dari Pasar Tradisional ke Pasar Modern di Kota Semarang. Semarang: Universitas Dipenogoro.

Soekartawi. (1995). Ilmu Usahatani. UI-Press. Jakarta.

Winardi, Deka I Djakarta. (2012). Pengaruh Marketing Mix Terhadap Keputusan Pembelian. Semarang: Universitas Dipenogoro. 